\title{
Review: Mr. Clement Ley's Work on Clouds
}

\section{Author(s): H. N. Dickson}

Review by: H. N. Dickson

Source: The Geographical Journal, Vol. 6, No. 2 (Aug., 1895), pp. 180-181

Published by: geographicalj

Stable URL: http://www.jstor.org/stable/1773745

Accessed: 27-06-2016 09:23 UTC

Your use of the JSTOR archive indicates your acceptance of the Terms \& Conditions of Use, available at

http://about.jstor.org/terms

JSTOR is a not-for-profit service that helps scholars, researchers, and students discover, use, and build upon a wide range of content in a trusted digital archive. We use information technology and tools to increase productivity and facilitate new forms of scholarship. For more information about JSTOR, please contact support@jstor.org.

The Royal Geographical Society (with the Institute of British Geographers), Wiley are collaborating with JSTOR to digitize, preserve and extend access to The Geographical Journal 
1. The Southern Shores of the Caspian, including Asterabad, Mazanderan, Gilan, and the Talish.

2. Mukri Kurdistan.

3. Elam.

\section{MR. CLEMENT LEY'S WORK ON CLOUDS.*}

By H. N. DICKSON, F.R.S.E.

Aт a time when the burning question amongst meteorologists is that of cloud classification and cloud nomenclature, it is specially satisfactory to have a complete summing up and judgment from one who has devoted the greater part of his life to a study of this subject, and who has long enjoyed a European reputation as a skilled observer of clouds. Innumerable as have been the improvements and modifications proposed from time to time on Howard's original nomenclature, these have hitherto consisted almost entirely of subdivisions of Howard's three great classes-the cirrus, the stratus, and the cumulus; and the divisions into intermediate forms have been for the most part quite: arbitrary, limited in number by the observer's supposed powers of discrimination. Mr. Ley takes advantage of our increased knowledge of the mechanism of atmospheric currents, and his book is an attempt to classify the results of his lifelong observation according to the different conditions which we now know give rise to the formation of clouds. Utilizing Helmholtz's deductions as to the ware surface of a current of air produced by another current of air flowing over it, Mr. Ley includes all the stratiform clouds under the term "Clouds of Interfret." Cumuliform clouds come under the heading "Clouds of Inversion," their formation being ascribed to condensation in ascending currents; and the luminous and cirriform clouds, formed of falling particles which tend to "lag" as they enter lower and more slowly moving" strata, are termed "Clouds of Inclination." Under these three types are included all the observed forms, except ground-fogs and haze, which are called "clouds of radiation," and the greater part of the book is devoted to a description of the species occurring under each bead as a con-

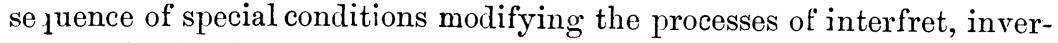
sion, or inclination. Seventeen species are considered sufficient to cover the most frequent cases, and the classification is completed by nine more specialized forms. Although the number of different kinds is considerable, the method at once commends itself as enabling the observer to connect each cloud-picture with distinct physical processes going on in the atmosphere.

In the latter part of the work the author discusses the general

* 'Cloudland: A Study on the Structure and Characters of Clouds.' By the Rev. W. Clement Lay. London: E. Stanford, 1894. 
circulation of the atmosphere as deduced by Ferrel from theoretical considerations, and compares the prevailing cloud-forms observed in different parts of the globe with those which would be produced, according to Mr. Ley's views, if Ferrel's circulation be correct. A chapter on the clouds of cyclones and anticyclones is practically a restatement of the author's celebrated investigations on the currents in these systems, but we note that Mr. Ley accepts the hypothesis that the ascending currents in cyclones originate through local heating at the Earth's surface, no explanation being given of Hann's conclusions as to the occurrence of cyclones where such conditions do not exist.

\section{THE SOUTHERN URALS : * RESULTS OF RECENT JOURNEYS.}

\section{By Dr. FUTTERER.}

THE opening of the new railway will mark the first stage of development of a district which, thanks to its extensive forests, abundant minerals, and unlimited water supply, bids fair to become one of the most important of the Russian Empire in Asia. Engineers and forestry experts from Western Europe, brought in contact with the work of the foundries and smelting-worls, have elicited the apparently paradoxical fact that the population of many of the mining and smelting districts in the Urals stands on a higher level of civilization than is found in regions west of the Volga. The central and southern Urals are easily accessible. The large saloon steamers on the Volga cover the distance from Nishni Novgorod to Samara in a little over forty hours; and Samara is the starting-point of the Siberian Railway. From Samara the central Urals are reached by steamer on the Kama river to Perm, and thence by rail to Tjumen. The two trans-Ural railways are to be united by a north and south line. From Samara the Siberian Railway runs via Ufa, Slatoust, and Miess to Chelyabinsk; and in September last the extension to Omsk was completed. To the east of Ufa the line rises gradually over successive plateaus to a great height, and the country only assumes a mountainous character between Slatoust and Miess in the Furesan basin, where the descent into Siberia has already begun. Deep cuttings, high bridges, and long stretches of steep rock-faces, showing marks of blasting, lead with many windings through the mountains, recalling the southern Black Forest Railway. Only tunnels are absent; these have been everywhere avoided, even at the expense of very deep cuttings, to prevent possible interruptions of traffic by their collapsing. The bridges are all of iron. The speed of the trains is not great; the journey from Samara to Chelyabinsk-a distance of 524 miles-occupies thirty-six hours, an average speed of $14 \frac{1}{2}$ miles an hour. Stoppages of three to forty minutes are made at every station, and buffets are provided at each. On the Moscow-Samara-Siberia line there are no sleeping or restaurant cars, but in the through trains two beds can be fitted in each compartment, for which the travellers must provide blankets and pillows.

The condition of the roads is an important matter in the industrial districts. Near the great smelting-works at Belarezk much has been done during the last fifteen years, and the main roads for bringing in supplies for the furnaces are extremely good. The road between the works and the railway station at Wasovaia, however, is in a terrible state even in dry weather, chiefly because it passes through properties not owned by the foundries.

* Abstract of paper read at the Barlin Geographical Socicty, November 3, 1894. 